\title{
Does the Late Approval of the State Budget Influences the Public Procurement Procedures in Romania?
}

\author{
Ionel PREDA ${ }^{\star}$
}

\begin{tabular}{l}
\hline \multicolumn{1}{c}{ A R T I C L E I N F O } \\
\hline Article history: \\
Accepted November 2019 \\
Available online December 2019 \\
\hline JEL Classification \\
C46, H57, H61, H72 \\
Keywords: \\
Public procurement, Procurement \\
procedure, State budget, \\
Procedures initiated, Procedures \\
finalised, Canceled procedures
\end{tabular}

\begin{abstract}
A B S T R A C T
In the last years the state budget in Romania has been promulgated with increasing delays. For that very reason, the research analyzes the possible influence of these delays on the initiation, conduct and annulment of the procedures. The study used the statistical data from two periods: first quarter from 2016 to 2019 and the period 2014-2018 (whole years) and examined the impact of the state budget delay on the features of the initiated procedures, 12 unifactorial linear regressions were performed. The results of these regressions revealed which of the features of the procedures were most influenced by the delays in promulgating the state budget. So far, no study in Romania or in the world has analyzed the effects of the delayed approval of the state budget on public procurement procedures.
\end{abstract}

(C) 2019 EAI. All rights reserved.

\section{Introduction}

Choosing when to initiate a procurement procedure is essential.

A public procurement procedure initiated too early may result in a reduced number of offers or higher prices (smaller savings) because the economic operators have to cover up an extended period of time to tendering, awarding and delivering the products, which implies coverage of inflation, currency risk, etc.

Also, a public procurement procedure initiated too late can have the following consequences:

- the delay of the moment of awarding and delivering the products;

- the occurrence of errors committed by the purchasers which could lead to the receipt of a large number of requests for clarification from the economic operators or even to cancelling the procedure;

- delays of the next stages of a project, in circumstances when the procedure is an early stage of a project.

The causes of delayed initiation and completion of procurement procedures can be multiple: the difficulty of establishing the technical specifications (for complex products / projects), negligence of the purchasers, late approval of the Romanian state budget.

This last cause became increasingly important, given that over the last 3 years, the Romanian state budget has been approved twice with great delays. In 2017 the Romanian state budget was adopted 48 days after the year has started, and in 2019 with a delay of 74 days after the year has started.

\section{Literature review}

The area of public procurement has been approached by many specialized studies from different perspectives. Uttam and Le Lann Roos, (2015) analyzed the role of procurement procedures in achieving sustainable development. Dufek, (2015) analyzed public procurement using econometric approaches, and Man, et al. (2014) analyzed the key factors which influence the transparency of Czech public procurement procedures.

Pavel, (2010) analyzed the influence of competition on savings achieved in Czech public procurement and Murray, (2009) studied economic crises and the role of public procurement in accelerating the economic recovery. Georghiou, et al., (2013) studied acquisitions as a trigger for innovation and TIR - Transparency International Romania, (2014) approached the corruption in public procurement in Romania and its consequences.

Governments are currently under pressure from public opinion to spend budget funds as efficiently as possible. A method of increasing the efficiency of procurement is the so-called "spend analysis".

Although this analysis was first adopted by private companies, over time this method has also been extended to public companies. In 2000, Kearney, (2002) conducted a survey in 147 private companies that revealed that the implementation of this type of analysis led to savings of about 13 billion dollars. 
The spend analysis was also used in the purchases based on cards made by the US Government which increased from 1994 to 2003 from 1 billion dollars to 16 billion dollars. Following such an analysis, the US federal agencies requested large suppliers to grant additional discounts (GAO - Government Accountability Office, 2004), so that in 2009, Thai et al., (2009) appreciated that by spend analysis and getting additional discounts in the US, savings of 300 million dollars / year could be achieved.

Also in the US, following such an analysis in 2003, the Office of Veterans Affairs obtained additional discounts from medical equipment and drug suppliers (GAO, 2001, GA0, 2002), saving 394 million dollars (Thai et al., 2009).

Even if the procurement field is very important for the Romanian economy, public procurement research in Romania is scarce. Even though public procurement has been studied from many perspectives, until now no research has analyzed the influence of the delay in approving the state budget on procurement procedures.

\section{Research Questions}

The research in this article aims to analyze a possible influence of the delay in adopting the state budget on procurement procedures. The research has tried to answer the following research questions:

- How procurement procedures have evolved between 2014 and 2018 ?

- Is the number of canceled procedures influenced by the delay in approving the Romanian state budget?

Given the political instability in Romania, these research questions are important topics for analysis for all stakeholders involved in conducting public procurement procedures.

\section{Research Methods}

The steps of the research methodology are: analysis of the specialized literature in the approached field; formulation of research questions; collecting the necessary data and information from the official statistics of National Agency for Public Procurement from Romanian (ANAP); actual analysis of data and elaboration of research results.

The statistical indicators, data and information used in the research were extracted from various statistical reports published by ANAP for the general public.

The use of indicators, data and information published by ANAP has the following advantages:

- the accuracy and relevance of the data are very high;

- the data cover the entire national territory of Romania and the entire period analyzed;

- the data comes from an electronic system in which data flows are automated and human intervention is minimal.

\section{Findings}

The draft laws on the state budget in Romania are drawn up by the Romanian Government and approved by the Romanian Parliament. According to the Law no. 500 / 11.07 .2002 regarding the public finances, the budget for the following year must be submitted by the Government to the Romanian Parliament for approval by 15 November at the latest.

Table 1 presents the evolution of the approvals of the Romanian state budget between 2014 and 2019. Because in three years out of the six years analyzed, the Romanian law of the state budget was adopted in about two weeks from the date of registration in the parliament, the delay was calculated between the moment of promulgation by the Parliament of Romania and the date of December 1 .

Table 1. The approvals of the budget from 2014 to 2019 in the Parliament of Romania

\begin{tabular}{|c|c|c|c|c|}
\hline $\begin{array}{c}\text { Budget } \\
\text { year }\end{array}$ & $\begin{array}{c}\text { Registration } \\
\text { date }\end{array}$ & $\begin{array}{c}\text { Approval date in } \\
\text { the two chambers }\end{array}$ & $\begin{array}{c}\text { Promulgation } \\
\text { date }\end{array}$ & $\begin{array}{c}\text { Duration of the delay } \\
\text { (calendar-days) }\end{array}$ \\
\hline 2014 & $11 / 15 / 2013$ & $12 / 04 / 2013$ & $12 / 18 / 2013$ & 18 \\
\hline 2015 & $12 / 13 / 2014$ & $12 / 21 / 2014$ & $12 / 29 / 2014$ & 29 \\
\hline 2016 & $12 / 09 / 2015$ & $12 / 16 / 2015$ & $12 / 18 / 2015$ & 18 \\
\hline 2017 & $01 / 31 / 2017$ & $02 / 07 / 2017$ & $02 / 16 / 2017$ & 47 \\
\hline 2018 & $12 / 07 / 2017$ & $12 / 22 / 2017$ & $01 / 03 / 2018$ & 34 \\
\hline 2019 & $02 / 09 / 2019$ & $02 / 15 / 2019$ & $03 / 15 / 2019$ & 74 \\
\hline
\end{tabular}

Sources: (ANAF - Romanian National Tax Administration Agency, 2013); (ANAF, 2014); (ANAF, 2015); (ANAF, 2017); (ANAF, 2018); (ANAF, 2019); (Cîtu, 2019) 


\subsection{The situation of procedures initiated during the first trimester from 2016 to 2019}

The features of the procurement procedures initiated during the 1st trimester from 2016 to 2019 are presented in Annex 1.

The evolution of the number of procedures initiated during the 1st trimester from 2016 to 2019 is represented in Figure 1.

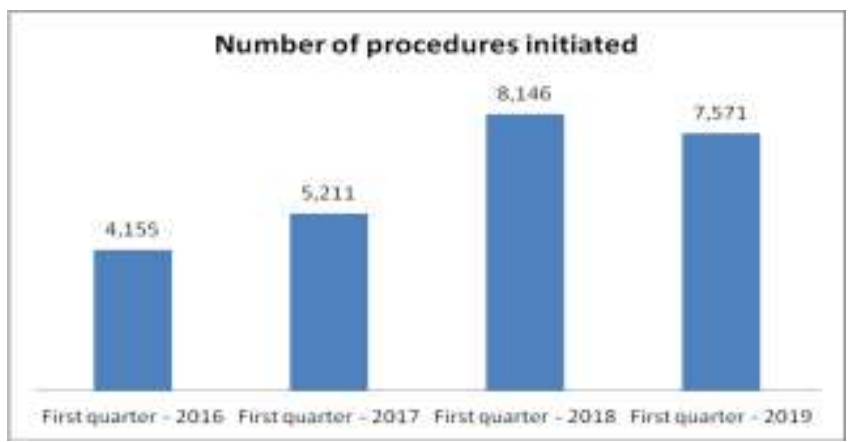

Figure 1. The evolution of the number of procedures initiated during the 1st trimester from 2016 to 2019

Sources: (ANAP, 2016a); (ANAP, 2017a); (ANAP, 2018a); (ANAP, 2019a)

As can be seen from Figure 1, the number of procurement procedures initiated dropped from 8,146 in the 1st trimester of 2018 to 7,571 in the 1st trimester of 2019 (in 2019 the approval of the state budget occured with the greatest delay - 74 calendar days).

The evolution of the estimated values increased from 8,727,553,332 euros in the 1st trimester of 2018 to $12,392,415,474$ euros in the 1 st trimester of 2019 (Figure 2).

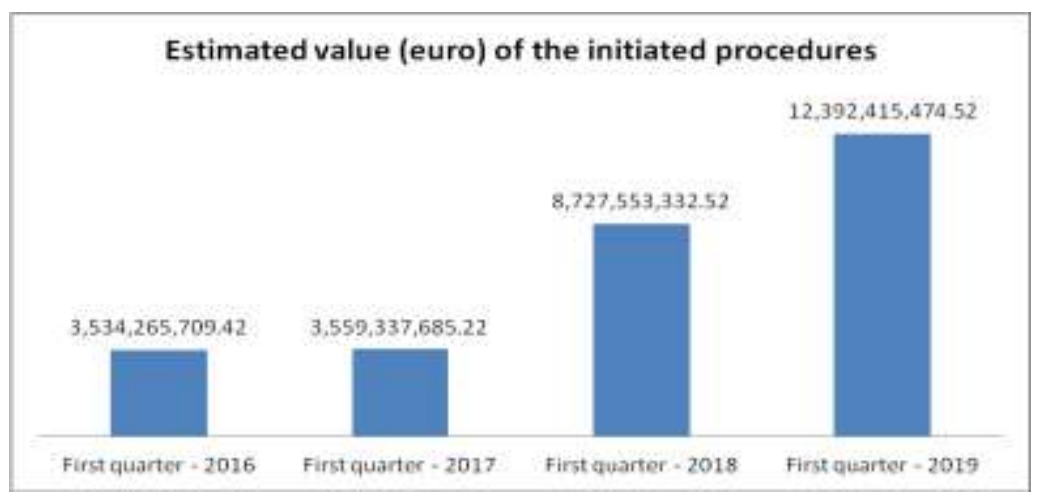

Figure 2. The evolution of the estimated values of the procedures initiated from 2016 to 2019 Sources: (ANAP, 2016a); (ANAP, 2017a); (ANAP, 2018a); (ANAP, 2019a)

Figure 3 shows the number of procedures initiated and finalised by awarding the contract or canceling the procedure during the analyzed period (lines 4.1 and 4.2 of Annex 1). It can be observed that the canceled procedures has gone up from 350 in 2016 to 1,488 in 2019.

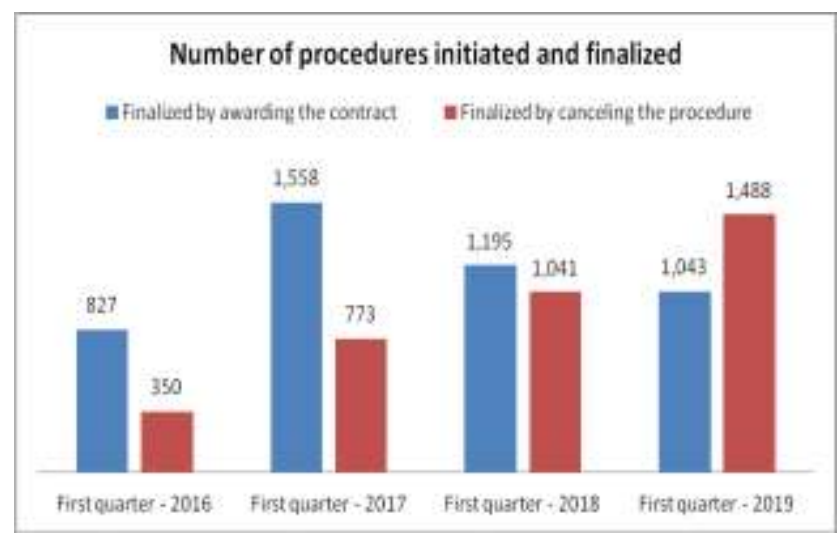

Figure 3. The evolution of the number of procedures initiated and finalized by awarding the contract or canceling the procurement procedure between 2016 and 2019 Sources: (ANAP, 2016a); (ANAP, 2017a); (ANAP, 2018a); (ANAP, 2019a) 
In Table 2, we verify the existence of a possible correlation between the delay of the Romanian state budget and the number of canceled procedures during the 1st trimester from 2016 to 2019. For this we use a linear unifactorial regression model with the following form:

where:

$$
y=a+b x
$$

$\mathrm{y}$ - number of canceled procurement procedures (line 4.2 of Annex 1);

$\mathrm{x}$ - delay of the Romanian state budget in calendar days (line 5 of Annex 1);

a - residual variable which indicating the insignificant influences on y variable;

$\mathrm{b}$ - coefficient of the variable $\mathrm{x}$.

Table 2. The regression model ( $y$ - number of procedures canceled, $x$ - delay duration of the promulgation of the Romanian state budget)

\begin{tabular}{|c|c|c|c|c|c|}
\hline \multicolumn{2}{|c|}{ Regresion Statistics } & & & & \\
\hline Multiple R & 0.890083 & & & & \\
\hline $\mathrm{R} \mathrm{Sq}$ & 0.792248 & & & & \\
\hline Adjusted R Sq & 0.688372 & & & & \\
\hline Standard Err & 266.4722 & & & & \\
\hline Observation & 4 & & & & \\
\hline \multicolumn{6}{|l|}{ ANOVA } \\
\hline & $\mathrm{df}$ & SS & MS & $\mathrm{F}$ & Signif. F \\
\hline Regression & 1 & 541563.1 & 541563.1 & 7.626851 & 0.109917 \\
\hline Residual & 2 & 142014.9 & 71007.44 & & \\
\hline Total & 3 & 683578 & & & \\
\hline
\end{tabular}

\begin{tabular}{|c|c|c|c|c|c|c|c|c|}
\hline & Coefficient & $\begin{array}{c}\text { Standard } \\
\text { Err }\end{array}$ & t Stat & P-value & Below 95\% & $\begin{array}{c}\text { Above } \\
95 \%\end{array}$ & $\begin{array}{l}\text { Below } \\
95.0 \%\end{array}$ & $\begin{array}{l}\text { Above } \\
95.0 \%\end{array}$ \\
\hline Intercept & 137.1088 & 310.9413 & 0.440947 & 0.702337 & -1200.76 & 1474.981 & -1200.76 & 1474.981 \\
\hline X Variable 1 & 17.93968 & 6.495942 & 2.761675 & 0.109917 & -10.0101 & 45.88946 & -10.0101 & 45.88946 \\
\hline
\end{tabular}

It can be seen that the free term (intercept) has the value $a=137.10$, which means that if there was no delay in approving the Romanian state budget, according to the regression model, there would be 137 procurement procedures canceled. The coefficient of the independent variable (b) has the value 17.93, which means that as the budget delay is increased by one day, the number of canceled procedures will increase by 17.93. The correlation ratio $(\mathrm{R}=0.890)$ indicates that between the number of procedures canceled and the delay of the Romanian budget is a stong connection. The degree of determination $\left(\mathrm{R}^{2}\right)$ has the value of 0.7922 and it indicates that $79.22 \%$ of the variation in the number of procedures canceled (y) is explained by the delay of the Romanian budget $(\mathrm{x})$.

The explanation of the canceled procedures is that a part of the contracting authorities initiate procurement procedures without the budget being approved. According to the legislation in force in Romania, a contracting authority can initiate a procurement procedure without having an approved budget, but can only conclude a contract when it has the necessary budgetary funds. When the budget is promulgated in a diminished form (at values lower than expected) and the procurement procedure is in progress, a contracting authority can only cancel the procedure.

In Table 3 we verify the existence of a possible correlation between the delay of the Romanian state budget and the estimates value (euro) of canceled procedures in the 1st trimester from 2016 to 2019 . For this we use a linear unifactorial regression model with the following form:

where:

$$
y=a+b x
$$

$y$ - estimated value (euro) of the canceled procurement procedures (line 4.2 of Annex 1);

$\mathrm{x}$ - delay of the Romanian state budget in calendar days (line 5 of Annex 1);

a - residual variable which indicating the insignificant influences on y variable;

$\mathrm{b}$ - coefficient of the variable $\mathrm{x}$. 
Table 3. The regression model ( $y$ - estimated value (euro) of canceled procedures, $x$ - delay of the Romanian state budget)

\begin{tabular}{cc}
\hline \multicolumn{2}{c}{ Regression Statistics } \\
\hline Multiple R & 0.98822 \\
R Sq & 0.976579 \\
Adjusted R Sq & 0.964868 \\
Standard Err & 60469904 \\
Observation & 4 \\
\hline
\end{tabular}

\begin{tabular}{cccccc}
\hline ANOVA & \multicolumn{5}{c}{} \\
\hline & $\mathrm{df}$ & $\mathrm{SS}$ & $\mathrm{MS}$ & $\mathrm{F}$ & Signif. F \\
\hline Regression & 1 & $3.05 \mathrm{E}+17$ & $3.05 \mathrm{E}+17$ & 83.3925 & 0.01178 \\
Residual & 2 & $7.31 \mathrm{E}+15$ & $3.66 \mathrm{E}+15$ & & \\
Total & 3 & $3.12 \mathrm{E}+17$ & & & \\
\hline
\end{tabular}

\begin{tabular}{ccccccccc}
\hline & & Standard & & & & & Above \\
& Coefficient & Err & t Stat & P-value & Below 95\% & Above 95\% & $95.0 \%$ & $95.0 \%$ \\
\hline Intercept & -147990375 & 70561161 & -2.09733 & 0.170879 & $-4.5 \mathrm{E}+08$ & $1.56 \mathrm{E}+08$ & $-4.5 \mathrm{E}+08$ & $1.56 \mathrm{E}+08$ \\
X Variable 1 & 13461485 & 1474109 & 9.131949 & 0.01178 & 7118908 & 19804062 & 7118908 & 19804062 \\
\hline
\end{tabular}

Source: author's calculations

It can be seen that the free term (intercept) has the value $a=-147,990,375$ which means that if there was no delay in approving the Romanian state budget, according to regression model, the estimated value of the procedures canceled would be $-147,990,375$ euro. The coefficient (b) has the value $13,461,485$, which means that as the budget delay is increased by one day, then the estimated value of the canceled procedures will increase by $13,461,485$ euro. The correlation ratio $(R=0.988)$ shows that there is a significant link between the estimated value of the procedures canceled and the delay of the Romanian budget. As can be seen, the degree of determination $\left(\mathrm{R}^{2}\right)$ is 0.9765 and it reveals that $97.65 \%$ of the change in the estimated values (y) is explained by the delays in approving the Romanian budget (x).

\subsection{The situation of public procurement procedures initiated from 2014 to 2018}

Annex 2 presents the situation of the procedures initiated in Romania (during each whole year) between 2014 and 2018 .

Figure 4 shows the evolution of the procedures initiated from 2014 to 2018.

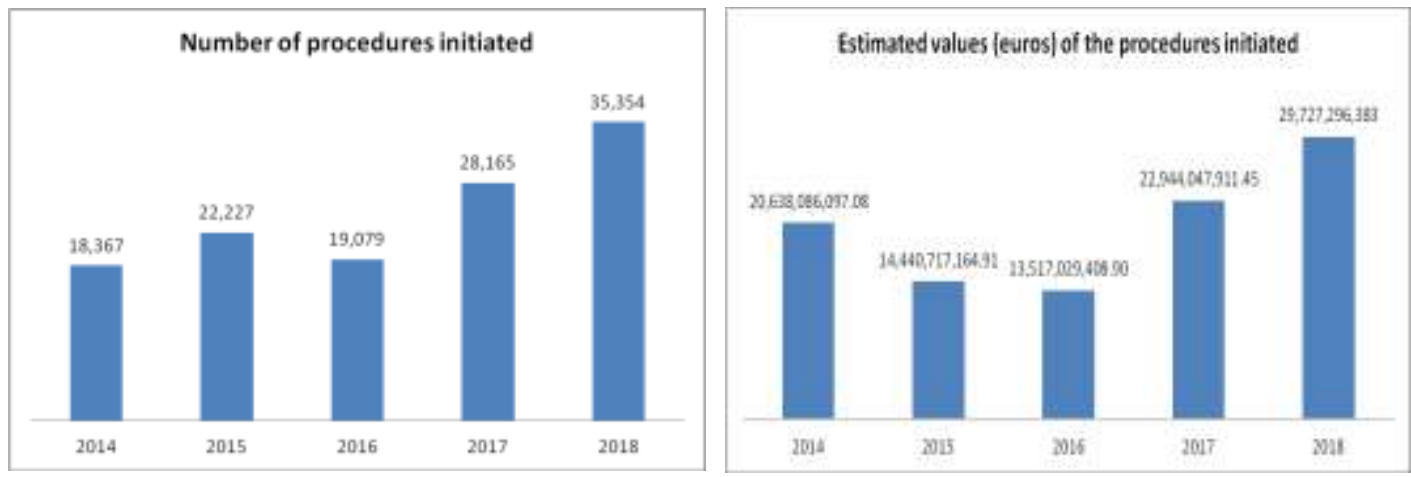

Figure 4. The evolution of the procedures initiated in Romania from 2014 to 2018

Sources: (ANAP, 2015a); (ANAP, 2015b); (ANAP, 2016b); (ANAP, 2016c); (ANAP, 2017b); (ANAP, 2018c)

As can be seen, from 2016 to 2018, the estimated values and number of the initiated procedures has increased steadily (practically doubled). This shows that over the past three years' additional funds have been distributed for the purchase of works, services and products.

In order to examine the connection between the features of the initiated procedures and the delay of the Romanian state budget, twelve unifactorial linear regressions were carried out in Annex 3.

The twelve regressions show that the highest correlation reports (R) and degrees of determination $\left(R^{2}\right)$ were obtained for the estimated values and number of the canceled procedures in the 1st trimester from 2016 to 2019 (Table 4). These two regressions were presented in detail above and show that there are significant connections between the delay of the Romanian state budget and the estimated value, 
respectively the number of procurement procedures canceled in the 1st trimester from 2016 to 2019. Also, according to the regressions performed, $97.7 \%$ of the variation in the estimated value and $79.2 \%$ of the variation in the number of the canceled procedures are explained by the delay of the state budget.

Table 4. The twelve unifactorial linear regressions performed

\begin{tabular}{|c|c|c|c|c|}
\hline $\begin{array}{l}\text { Dependent variable } \\
(y=a+b x)\end{array}$ & $\mathbf{R}$ & $\mathbf{R}^{2}$ & $\mathbf{R}$ & $\mathbf{R}^{2}$ \\
\hline Period analyzed & \multicolumn{2}{|c|}{ First quarter 2016-2019 } & \multicolumn{2}{|c|}{ 2014-2018 } \\
\hline $\begin{array}{l}\text { Number of procedures initiated and } \\
\text { finalized by cancellation of the procedure }\end{array}$ & 0.890 & 0.792 & 0.641 & 0.410 \\
\hline $\begin{array}{l}\text { Estimated value for the procedures } \\
\text { initiated and finalized by cancellation of } \\
\text { the procedure (euro) }\end{array}$ & 0.988 & 0.977 & 0.130 & 0.017 \\
\hline $\begin{array}{c}\text { Weight of the number of procedures } \\
\text { initiated and finalized by cancellation of } \\
\text { the procedure }(\%)\end{array}$ & 0.794 & 0.630 & 0.664 & 0.441 \\
\hline $\begin{array}{l}\text { Weight of the estimated values (euro) of } \\
\text { the procedures initiated and finalized by } \\
\text { cancellation of the procedure (\%) }\end{array}$ & 0.856 & 0.732 & 0.068 & 0.005 \\
\hline
\end{tabular}

Source: author's calculations

From the comparative analysis of the correlation ratios $(R)$ and the degrees of determination $\left(R^{2}\right)$ for the two analyzed periods, it can be seen that these indicators are higher for the 1st trimester from 2016 to 2019 compared to the period 2014-2018 (whole years). These results show that the delay in approving the state budget influences the procedures canceled in the 1st trimester more than the procedures canceled during a whole year.

\section{Conclusions}

The present research analyzes the connection between the features of procurement procedures and the delay of the state budget.

After comparing the statistical data of two periods: 1st trimester of 2016-2019 and 2014-2018 (whole years) and a number of twelve unifactorial linear regressions were conducted, research has shown that there are significant connections between the delay of the Romanian state budget and the estimated value, respectively the number of procurement procedures canceled in the 1st trimester from 2016 to 2019.

Also, the research concluded that the delay in promulgating the state budget influences more the procedures canceled in the 1st trimester than the procedures canceled during a whole year.

Future research should identify other factors that influence the cancellation of the procurement procedures. A difficult challenge may be to establish causal relationships and isolate the effects generated by these factors on features of the canceled procurement procedures.

\section{References}

1. ANAF (2013), 'Legea bugetului de stat pe anul 2014, Publicată în Monitorul Oficial nr. 805 din 19.12.2013', [Online], https://static.anaf.ro/static/10/Anaf/legislatie/L_356_2013.pdf, Accesed 14 september 2019

2. ANAF (2014), 'Legea bugetului de stat pe anul 2015, Publicată în Monitorul Oficial nr. 960 din 30.12 .2014 ', [Online], https://static.anaf.ro/static/10/Anaf/legislatie/L_186_2014.pdf, Accesed 14 september 2019

3. ANAF (2015), 'Legea nr. 339/18.12.2015 - Legea bugetului de stat pe anul 2016, Publicată în Monitorul Oficial nr. 941 din 19.12.2015', [Online], https://static.anaf.ro/static/10/Anaf/legislatie/L_339_2015.pdf, Accesed 14 september 2019

4. ANAF (2017) Romanian National Tax Administration Agency, 'Legea nr. 6/16.02.2017 - Legea bugetului de stat pe anul 2017, Publicată în Monitorul Oficial nr. 127 din 17.02.2017', [Online], https://static.anaf.ro/static/10/Anaf/legislatie/L_6_2017.pdf, Accesed 14 september 2019

5. ANAF (2018), 'Legea nr. 2/03.01.2018 - Legea bugetului de stat pe anul 2018, Publicată în Monitorul Oficial nr. 4 din 03.01.2018', [Online], https://static.anaf.ro/static/10/Anaf/legislatie/L_2_2018.pdf, Accesed 14 september 2019

6. ANAF (2019), 'Legea nr. 50/15.03.2019 - Legea bugetului de stat pe anul 2019, Publicată în Monitorul Oficial nr. 209 din 15.03.2019', [Online], https://static.anaf.ro/static/10/Anaf/legislatie/L_50_2019.pdf, Accesed 14 september 2019

7. ANAP (2015a), 'Raport statistic 01 ianuarie - 31 decembrie 2015 privind procedurile de atribuire a contractelor de achiziție publică inițiate prin publicarea de anunț de participare sau invitație de participare în cadrul SEAP', [Online], http://anap.gov.ro/web/wpcontent/uploads/2016/02/RAPORT-STATISTIC-2015_Site-ANAP.pdf, Accesed 24 august 2019

8. ANAP (2015b), 'Analiza procedurilor de atribuire a contractelor de achiziție publică inițiate în perioada 2014 - 2015', [Online], http://anap.gov.ro/web/wp-content/uploads/2016/02/ANALIZ\%C4\%82-PROCEDURI-AP-2014-2015_-Rap-statistice.pdf, Accesed 24 august 2019

9. ANAP (2016a), 'Sistemul de achiziții publice din România - Trimestrul I 2016', [Online], http://anap.gov.ro/web/wpcontent/uploads/2016/05/SITUATIE-APIP-TRIM-I-2016.pdf, Accesed 24 august 2019

10. ANAP, (2016b), 'Raport statistic 01 ianuarie - 31 decembrie 2016 privind procedurile de atribuire a contractelor de achiziție publică inițiate prin publicarea de anunț de participare sau invitație de participare în cadrul SEAP', [Online], http://anap.gov.ro/web/wpcontent/uploads/2017/02/Raport-februarie-2017.pdf, Accesed 25 august 2019 
11. ANAP, (2016c), 'Analiza procedurilor de achiziție publică în perioada 2015 - 2016', [Online], http://anap.gov.ro/web/wpcontent/uploads/2018/01/ANALIZA-APIP-INITIATE-2015-2016.pdf, Accesed 25 august 2019

12. ANAP (2017a), 'Raport statistic 01 ianuarie - 31 martie 2017 privind procedurile de atribuire a contractelor de achiziție publică/sectoriale inițiate în cadrul SEAP prin publicare de anunț de participare/anunț de participare simplificat/invitație de participare', [Online], http://anap.gov.ro/web/wp-content/uploads/2017/05/RAPORT-STATISTIC-APIP-TRIMESTRUL-I-2017.pdf, Accesed 25 august 2019

13. ANAP (2017b), 'Raport statistic 01 ianuarie - 31 decembrie 2017 privind procedurile de atribuire a contractelor de achiziție publică/sectoriale inițiate în cadrul SEAP prin publicare de anunț de participare/anunț de participare simplificat/invitație de participare', [Online], http://anap.gov.ro/web/wp-content/uploads/2018/02/Situatie-APIP-an-2017.pdf, Accesed 26 august 2019

14. ANAP (2018a), 'Raport statistic Trimestrul I 2018 proceduri de atribuire a contractelor de achiziție publică/sectoriale inițiate în cadrul S.E.A.P. prin publicare de anunț de participare/anunț de participare simplificat/invitație de participare', [Online], http://anap.gov.ro/web/wp-content/uploads/2018/05/SITUATIE-PROCEDURI-INITIATE-TRIM-I-2018.pdf, Accesed 26 august 2019

15. ANAP (2018b), 'Raport statistic 01 ianuarie - 30 iunie 2018 privind procedurile de atribuire a contractelor de achizitie publică/sectoriale inițiate în cadrul SEAP/SICAP prin publicare de anunț de participare/anunț de participare simplificat/invitație de participare', [Online], http://anap.gov.ro/web/wp-content/uploads/2019/01/RAPORT-STATISTIC-APIPAPS-Semestrul-II-2018.pdf, Accesed 27 august 2019

16. ANAP (2018c), 'Raport statistic 01 ianuarie - 31 decembrie 2018 privind procedurile de atribuire a contractelor de achiziție publică/sectoriale inițiate în cadrul SEAP/SICAP prin publicare de anunt de participare/anunt de participare simplificat/invitație de participare', [Online], http://anap.gov.ro/web/wp-content/uploads/2019/02/raport-statistic-2018_05Feb2019.pdf, Accesed 27 august 2019

17. ANAP (2019a), 'Raport statistic 01 ianuarie - 31 martie 2019 privind procedurile de atribuire a contractelor de achiziție publică/sectoriale inițiate în cadrul Sistemului Electronic de Achiziții Publice prin publicare de anunt de participare/anunt de participare simplificat/invitație de participare', [Online], http://anap.gov.ro/web/wp-content/uploads/2019/06/Sinteza-proceduriinitiate-trim-I-2019-TR.pdf, Accesed 27 august 2019

18. ANAP (2019b), 'Raport statistic 01 ianuarie - 30 iunie 2019 privind procedurile de atribuire a contractelor de achizitie publică/sectoriale inițiate în cadrul Sistemului Electronic de Achiziții Publice prin publicare de anunț de participare/anunț de participare simplificat/invitație de participare', [Online], http://anap.gov.ro/web/wp-content/uploads/2019/08/Raport-statisticinitiate-01.01.2019-30.06.2019.pdf, Accesed 27 august 2019

19. Cîtu, F. (2019) - 'Factual - Despre aprobarea (si întârzierea) bugetului național', [Online], https://www.factual.ro/declaratii/florincitu-despre-intarzierea-bugetului-si-datoria-publica-din-2018/, Accesed 14 september 2019

20. Dufek, L. (2015), 'Public Procurement: A Panel Data Approach', Procedia Economics and Finance, 25, 535-542

21. GAO - Government Accountability Office (2001), May 25, 'DOD and VA Pharmacy: Progress and Remaining Challenges in Jointly Buying and Mailing Out Drugs' (GAO-01-588), Washington, cited in Thai, K. V. et al (2009), 'International Handbook of Public Procurement', p. 548, Ed. Taylor \& Francis Group

22. GAO (2002), July 22, 'VA and DOD Health Care: Factors Contributing to Reduced Pharmacy Costs and Continuing Challenges', (GAO-02969T), cited in Thai, K. V. et al (2009), 'International Handbook of Public Procurement', p. 548, Ed. Taylor \& Francis Group

23. GAO (2004), March 12, 'Contract Management: Agencies Can Achieve Significant Savings on Purchase Card Buys', (GAO-04-430), Government Accountability Office (2004), April 28, 'Purchase Cards: Increased Management Oversight and Control Could Save Hundreds of Millions of Dollars', (GAO-04-717T) cited in Thai, K. V. et al (2009), 'International Handbook of Public Procurement', p. 548, Ed. Taylor \& Francis Group

24. Georghiou, L., Edler, J., Uyarra, E., Yeow, J. (2013), 'Policy instruments for public procurement of innovation: Choice, design and assesment', Technological Forecasting \& Social Change, 86, 1-12

25. Kearney, A., T. (2002), 'Assessment of Excellence in Procurement', cited in Thai, K. V. et al., (2009), 'International Handbook of Public Procurement', p. 544, Ed. Taylor \& Francis Group

26. Man, P., Matějková, J., Jurčík, R., Heidu R. (2014), 'The Key Factors of Transparency of the Public Procurement in the Czech Republic', Procedia Economics and Finance, 12, 379-386

27. Murray, J., G. (2009), 'Public procurement strategy for accelerating the economic recovery', pp. 8-9, [Online], https://www.researchgate.net/profile/J_Murray3/publication/254189230_Public_procurement_strategy_for_accelerating_the_econom ic_recovery/links/54cf6bc50cf24601c093741c.pdf, Accesed 29 octomber 2019

28. Pavel, J. (2010), 'Analyza vlivu miry koncurence na cenu rozsahlych staveb v dopravni infrastruktury', Politicka ekonomie, 14, 343-356, cited în Grega, M., Nemec, J., (2015), 'Factors Influencing Final Price of Public Procurement: Evidence from Slovakia', Procedia Economics and Finance, 25, $543-551$

29. Thai, K. V. et al. (2009), 'International Handbook of Public Procurement', pp. 2 - 780, Ed. Taylor \& Francis Group

30. TIR - Transparency International Romania (2014), 'Riscuri de corupție în achizițiile publice - Excelență și integritate în achizițiile publice', [Online], https://www.transparency.org.ro/proiecte/proiecte_incheiate/2010/proiect_3/Riscuri\%20de\%20coruptie\%20in\%20achizitii\%20pub lice.pdf, Accesed 3 july 2019

31. Uttam, K. and Le Lann Roos, C. (2015), 'Competitive dialogue procedure for sustainable public procurement', Journal of Cleaner Production, 2015, 403-416 